\title{
Üliõpilaste arusaamad plagiaadist ja plagiaadituvastussüsteemidest
}

\author{
Marvi Remmik $^{a^{1}}$, Tiina Tasa ${ }^{\mathrm{b}}$, Liana Roos ${ }^{\mathrm{c}}$, Erika Löfström ${ }^{\mathrm{d}}$ \\ a Tartu Ülikooli Viljandi kultuuriakadeemia \\ ${ }^{b}$ Tartu Biotehnoloogia Park \\ c Tartu Ülikooli haridusteaduste instituut \\ ${ }^{d}$ Helsingi Ülikooli haridusteaduste instituut
}

\begin{abstract}
Annotatsioon
Plagiaat on ülikoolides endiselt suur probleem. Tehnoloogia areng on võimaldanud üliõpilastele lihtsa juurdepääsu veebimaterjalidele, see aga mõjutab nende plagieerimiskäitumist, muutes selle levinumaks kui kunagi varem. Uurimuse eesmärk on välja selgitada üliõpilaste arusaamad plagiaadist ja plagiaadituvastussüsteemide kasutamisest. Selleks analüüsiti 380-lt eri valdkonna ja õppetaseme üliõpilaselt küsimustikuga kogutud andmeid, millest ilmneb, et üle poole vastajatest ei pea plagiaati levinud probleemiks ega tea täpselt, milles plagiaat seisneb. Sotsiaalteaduste ning humanitaarteaduste ja kunstide valdkonna üliõpilased on võrreldes loodus- ja täppisteaduste ning meditsiinivaldkonna üliõpilastega plagiaadi olemusest ja plagiaadituvastussüsteemidest teadlikumad. Plagiaadi leviku pidurdamiseks peetakse oluliseks ennetustööd: akadeemiliste tekstide kirjutamise oskuse ja õpioskuste arendamist, plagiaadi olemuse kohta ühtsete arusaamade kujundamist ja plagiaadijuhtumite menetlemiseks institutsioonisiseste eeskirjade kehtestamist. Plagiaadituvastussüsteemide kasutamine on üliõpilaste hinnangul õiglane, aga ka hirmu tekitav. Sellised tulemused osutavad vajadusele suurendada õppejõudude vastutust teema käsitlemisel ainekursuste raames.
\end{abstract}

Võtmesõnad: plagiaat, plagiaadituvastussüsteemid, ülikool, üliõpilased, akadeemiline petturlus 


\section{Sissejuhatus}

Tehnoloogia ja eri meediumite kiire areng on tekitanud olukorra, kus plagiaadist on saanud üks levinuimaid akadeemilise petturluse vorme kõrghariduses. Ühelt poolt lihtsustab üliõpilaste plagieerimiskäitumist internetis vabalt kättesaadavate allikate rohkus, teisalt on palju probleeme seotud ka nn tahtmatu plagiaadiga, mille põhjus on üliõpilaste vähene teadlikkus plagiaadist ja sellest hoidumise võimalustest (Chen \& Chou, 2017). Seejuures on plagiaat kujunenud üleilmseks probleemiks kõigil kõrgharidustasemetel. Nii on tuvastatud teistest allikatest pärit viitamata teksti veidi enam kui pooltes uuritud magistritöödes (Eckel, 2011) ning ligi pooltes analüüsitud doktoritöödes (Ison, 2012). Uus-Meremaal tehtud uuringuga leiti, et ligi veerand üliõpilaste esitatud töödest sisaldas plagiaati, kuigi enne oli uuritavatele selgitatud nii plagiaadi olemust kui ka plagiaadi vältimise võimalusi (Walker, 2010).

Üheks plagiaadi leviku piiramise võimaluseks peetakse plagiaadituvastussüsteemide kasutuselevõttu, mis annab üliõpilastele võimaluse iseseisvalt kontrollida eri allikate kasutamist ja neile viitamist oma tekstis (Eissen \& Stein, 2006; Evans, 2006). On küll leitud, et pärast plagiaadituvastussüsteemide kasutuselevõttu tajuvad üliõpilased plagiaadi olemust paremini (Löfström, Huotari, \& Kupila, 2017), kuid sellest hoolimata esineb üliõpilastöödes jätkuvalt nii tahtlikku kui ka tahtmatut (juhuslikku) plagiaati (Löfström \& Kupila, 2013). Tekib küsimus, et kui plagiaadituvastussüsteemid on levinud ning vabalt kättesaadavad, siis miks ei ole plagiaat üliõpilastöödest kuhugi kadunud või plagieerimine vähenenud. Üks võimalik selgitus võib olla üliõpilaste teadmatus sellest, mis ikkagi on plagiaat, aga ka sellest, et üliõpilaste ja õppejõudude arusaamad plagiaadist on erinevad.

\section{Plagiaadi olemus ja plagieerimise põhjused}

Teadlase eetika põhiküsimus on, milliseid eetilisi norme ja väärtusi peaks töös järgima. Plagiaati on peetud üheks tõsisemaks teadlase eetikat puudutavaks probleemiks ühes andmete (pahatahtliku) väljamõtlemise ja väärkasutusega. Esiteks on plagiaat vargus, kuna plagieerimise tõttu jääb originaalteksti autor ilma õigustatud tunnustusest. Teiseks on plagiaat lugeja petmine, kuna lugejale peab jääma võimalus hinnata esitatu usaldusväärsust ja õigsust (Lagerspetz, 2017). Hannabuss (2001) leiab, et „plagiaadi korral pole tegu ainult reeglite rikkumisega, vaid ka normide, väärtuste, ootuste ja kogukonna moraalsete uskumustega" (lk 312). Kõrghariduse kontekstis on plagiaat tähelepanu pälvinud eeskätt kultuurilistest erisustest, ideoloogiast ja ootustest tuleneva probleemina, seevastu plagiaat kui moraalne probleem ning headest tavadest üleastumine on jäänud pigem tagaplaanile (Hayes \& Introna, 2005). 
Kuna plagiaadi olemus on keeruline ja mitmetahuline, on püüdlustest hoolimata plagiaadi mõistet raske defineerida. Levinuima käsitluse kohaselt mõistetakse plagiaadina teis(t)e autori(te) töö või teksti esitamist enda omana algallikale viitamata (Bokosmaty, Ehrich, Eady, \& Bell, 2017; Chen \& Chou, 2017; Gullifer \& Tyson, 2014; Moss, White, \& Lee, 2018). Plagiaat ei seisne aga ainult teiste töö või teksti esitamises enda omana, vaid võib tähendada ka teiste autorite idee(de) laenamist (Myers, 2018). Ideede varguse kõrval on plagiaati nimetatud ka „kirjanduslikuks varguseks“ (Eret \& Gokmenoglu, 2010).

Plagiaadi mõistmise muudab keeruliseks seegi, et plagiaati on nii kontekstist kui ka individuaalsetest arusaamadest lähtudes võimalik erinevalt tõlgendada (Adam, Anderson, \& Spronken-Smith, 2017). Ka plagieerimise põhjusi saab selgitada nii kultuurilise ja institutsionaalse konteksti kui ka individuaalsete tegurite kaudu. Näiteks on leitud, et plagieerimine on enam levinud LadinaAmeerika ning Ida- ja Lõuna-Euroopa üliõpilaste seas, kuid näiteks Skandinaavia maades on plagiaat pigem harva esinev nähtus (Teixeira \& Rocha, 2010). Kultuurikonteksti kujundavad ka kaasüliõpilased, sest just nende käitumine mõjutab oluliselt üliõpilaste plagieerimiskäitumise valikuid (McCabe, Feghali, \& Abdallah, 2008; McCabe \& Trevino, 1997). Plagieerimispõhjuste institutsionaalse konteksti kujundavad õppejõudude hoiakud ja käitumine eksimuste avastamisel (Christensen Hughes \& McCabe, 2006; Tasa, 2018), seevastu individuaalsete teguritena on esile toodud näiteks madalat enesehinnangut, üliõpilase õppeaastat (Iyer \& Eastman, 2006), aga ka sugu ja vanust (Hensley, Kirkpatrick, \& Burgoon, 2013; Honig \& Bedi, 2012; McCabe \& Trevino, 1997).

Plagiaadil on eri vorme. Kõige levinum on teksti sõnasõnaline kopeerimine internetist ilma ühelegi allikale viitamata (Singh \& Remenyi, 2016). Sellega seostub teis(t)e üliõpilas(t)e töö osade või terve töö esitamine enda omana kas teis(t)e loal või loata (Walker, 2010). Ühe plagiaadivormina eristatakse mosaiikplagiaati, mille korral sõnasõnaline kopeerimine täies mahus küll puudub, ent teis(t)e idee(d) ja töö osad on esitatud enda omana, ilma et oleks korrektselt viidatud (Dhammi \& Haq, 2016). Plagiaadivormideks peetakse ka tsitaati, kus tekst on esitatud muutmata kujul, kuid puuduvad jutumärgid, samas on siiski teis(t)ele autori(te)le viidatud (Walker, 2010). Samuti peetakse plagiaadiks viitamata ümbersõnastamist, mille korral on teis(t)e autori(te) idee(d) oma sõnadega edasi antud, kuid originaalautori(te)le on jäetud tekstis viitamata (Dhammi \& Haq, 2016; Flint, Clegg, \& Macdonald, 2006; Myers, 2018). Lisaks ei tule üliõpilased sageli selle peale, et ka enda varasematele (avaldatud) töödele on vaja viidata. Nendel juhtudel on tegu eneseplagiaadiga (Dhammi \& Haq, 2016; Myers, 2018). Üha suuremaks probleemiks on kujunemas ka keeltevaheline plagiaat, mille korral tõlgitakse tekst ühest keelest teise, viitamata algallikale korrektselt (Ferrero, Schwab, Besacier, \& Agnes, 2017). Nagu eelnevast 
ilmneb, on plagiaadi olemus keeruline ja levinud tõlgendused ei hõlma kõiki võimalikke plagiaadivorme.

Põhjusi, miks üliõpilased plagieerivad, on mitmesuguseid, kuid üldjoontes eristatakse tahtlikku (teadlikku) ja tahtmatut plagiaati (Kayaoğlu, Erbay, Flitner, \& Saltaş, 2016). Tahtliku plagiaadi ühe põhjusena on esile toodud ajapuudust (Chankova, 2017; Kayaoğlu et al., 2016; Sarwar, Moin, \& Jabeen, 2016), üliõpilaste laiskust (Chen \& Chou, 2017), negatiivset suhtumist kodutöödesse (Chankova, 2017), õpetatava aine vastu huvi puudumist (Chen \& Chou, 2017) või lihtsat ligipääsu internetiallikatele (Kayaoğlu et al., 2016; Sarwar et al., 2016). Tahtliku plagieerimise kasuks võivad otsustada ka need üliõpilased, kelle arvamuse kohaselt plagieerivad ühel või teisel viisil kõik üliõpilased ning kes peavad vahelejäämist vähetõenäoliseks (Bokosmaty et al., 2017; Ewing, Mathieson, Anast, \& Roehling, 2017; Kayaoğlu et al., 2016). Karistamatusetunnet võib süvendada ka õppejõudude ükskõiksus ja plagiaadijuhtumitele reageerimata jätmine (Chankova, 2017).

Tahtmatu plagiaadi põhjused on enamasti üliõpilaste teadmatus ja oskamatus, sealhulgas näiteks vähene akadeemiliste tekstide kirjutamise kogemus (Chankova, 2017; Chen \& Chou, 2017; Sarwar et al., 2016) või korrektse viitamise oskus (Kayaoğlu et al., 2016). Tahtmatu plagiaadi esinemist üliõpilastöödes võib põhjustada ka ülesande mittemõistmine (Kayaoğlu et al., 2016), oskamatus eristada viitamist vajavat materjali üldtuntud teadmistest (Gullifer \& Tyson, 2014) ning teadmatus sellest, mis viitamisstiil valida (Adam et al., 2017). Kuna teadusvaldkondade viitamistavad on erinevad, võib see tekitada segadust üliõpilastes, kes valivad ülikoolis õppeaineid eri teaduskondadest.

\section{Plagiaadi leviku pidurdamise võimalused}

Plagiaadi leviku pidurdamisel on peetud kõige tõhusamaks ülikoolide ja õppejõudude koostööd (Ewing et al., 2017). On tähtis, et ülikoolides oleks kokku lepitud, mida plagiaadiks peetakse, ning kehtestatud ühtne reeglistik, kuidas plagiaadi levikut piirata ja plagiaadijuhtumite korral käituda (Bokosmaty et al., 2017). Marshall ja Garry (2005) leiavad, et plagiaadi olemus tuleks avada konkreetsete näidete kaudu ning sel juhul saavad üliõpilased kõrvutada enda tööd esitatud näidetega ja teha järeldusi plagiaadi esinemise või mitteesinemise kohta.

Plagiaadi vähendamiseks soovitatakse õppejõududel oma õppeaine sissejuhatuses selgitada plagiaadi olemust ning tutvustada üliõpilastele reegleid, millest lähtutakse plagiaadi avastamisel (Chen \& Chou, 2017). Kuna plagiaat võib olla tingitud ka akadeemiliste tekstide kirjutamise vähestest oskustest, siis on oluline tutvustada üliõpilastele juba varakult akadeemilisi tavasid (Babaii 
\& Nejadghanbar, 2017). Eelnimetatule lisaks eksivad üliõpilased info kasutamise põhimõtete vastu. Seega on tänapäeva infoühiskonnas tähtis, et interneti kasutamist ja sellega kaasnevat, sh autoriõigusi, tutvustataks õpilastele juba üldhariduskoolis (Marshall \& Garry, 2005). Ennetamine ja varane sekkumine toetavad õige käitumise juurdumist ning tänu sellele esineb ka kõrgematel haridusastmetel vähem probleeme.

Eespool loetletud abinõud on mõeldud pigem tahtmatu plagiaadi ennetamiseks, ent üliõpilastöödes esineb sageli ka tahtlikku plagiaati. Chankova (2017) näeb tahtliku plagiaadi ennetamise ja vähendamise võimalusena õppeprotsessi, mitte õpitulemuste väärtustamist. Lisaks saavad õppejõud anda üliõpilastele atraktiivsemaid ülesandeid, mis nõuavad teadmiste rakendamist, individuaalset analüüsi ja sünteesi ning mille vastuseid ei saa internetist lihtsa vaevaga kätte (Espinoza \& Nájera, 2015; Seifried, Lenhard, \& Spinath, 2015).

Plagiaadi leviku piiramisel on peetud tõhusaks abivahendiks plagiaadituvastussüsteeme, mis võimaldavad nii üliõpilastel kui ka õppejõududel oma tekste kontrollida. Õppejõududele ja üliõpilastele on internetist kättesaadavad erinevad plagiaadituvastussüsteemid, nagu Turnitin ${ }^{2}$, Grammarly ${ }^{3}$, Plagramme ${ }^{4}$, Quetext ${ }^{5}$, PlagScan ${ }^{6}$. Eesti ülikoolides on enim kasutust leidnud plagiaadituvastussüsteemid $\mathrm{Kratt}^{7}$ ja Urkund ${ }^{8}$. Plagiaadituvastussüsteemid võrdlevad töös sisalduvat teksti süsteemile kättesaadavate allikate tekstiga. Siit tuleneb aga plagiaadituvastussüsteemide peamine piirang: need ei tuvasta materjale, mida ei leidu internetis. Lisaks ei suuda plagiaadituvastussüsteemid alati avastada keeltevahelist plagiaati (Ferrero et al., 2017).

Varasemad uuringud on näidanud, et õppejõud suhtuvad plagiaadituvastussüsteemidesse mõneti kahtlevalt ja kriitiliselt, kuna keeruliste ja aeganõudvate süsteemide kasutamine tähendab neile lisatööd (Sattler, Wiegel, \& van Veen, 2017). Peale selle tekitab küsimusi, kes peaks üliõpilase töid süsteemis kontrollima - kas üliõpilane või õppejõud (Chew, Ding, \& Rowell, 2015). Õppejõudude arvates arendab oma töö kontrollimine üliõpilaste ümbersõnastusoskust, kuid teisalt võivad üliõpilased kasutada süsteemi vaid plagiaadi peitmise eesmärgil, mis võib aga tähendada seda, et nad sõnastavad ümber ainult selle osa tekstist, kust leiti kattuvus (Sarwar et al., 2016).

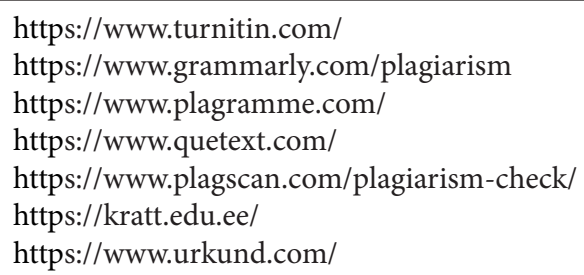


Üliõpilastes tekitab kõhklusi ja kriitikat aga see, et plagiaadituvastussüsteemid võetakse enamasti kasutusele vaid kontrollimise ja karistamise eesmärgil (Bruton \& Childers, 2016; Löfström \& Kupila, 2013). Löfström ja Kupila (2013) on leidnud, et üliõpilased ei näe plagiaadituvastussüsteemis võimalust arendada akadeemiliste tekstide kirjutamise oskust. Küll aga muudab plagiaadituvastussüsteemide kasutamine nii üliõpilased kui ka õppejõud plagiaadist teadlikumaks (Löfström et al., 2017), mistõttu oleks kõige efektiivsem lasta üliõpilastel plagiaadituvastussüsteeme siiski ise kasutada.

Seega võib öelda, et plagiaadi keerulise olemuse tõttu ei oska üliõpilased plagiaadivorme alati ära tunda ning seetõttu ka plagieerimisest hoiduda. Plagiaadi leviku vähendamiseks tuleks üliõpilastele tutvustada akadeemilisi tavasid, sh õpetada korrektset viitamist, samuti on vaja selgitada plagiaadi olemust ning internetist leitava info kasutamise põhimõtteid. Plagiaadituvastussüsteemide kaasabil saavad üliõpilased oma kirjalikke töid kontrollida ning seeläbi õppida ja arendada akadeemiliste tekstide kirjutamise oskust.

Artikli aluseks oleva uuringu eesmärk on välja selgitada üliõpilaste arusaamad plagiaadist ja plagiaadituvastussüsteemidest. Uuringu käigus otsiti vastuseid järgmistele uurimisküsimustele.

1. Millised on üliõpilaste arusaamad plagiaadist ja selle esinemise põhjustest?

2. Millised on üliõpilaste arusaamad plagiaadituvastussüsteemidest?

3. Mis võimalusi näevad üliõpilased plagiaadi leviku pidurdamiseks?

4. Mis erinevused ilmnevad eri teadusvaldkondade üliõpilaste arusaamades plagiaadist, selle esinemise põhjustest, plagiaadituvastussüsteemidest ja plagiaadi leviku pidurdamise võimalustest?

\section{Meetod}

\section{Valim ja andmekogumine}

Andmeid koguti bakalaureuse- ja magistritaseme üliõpilastelt, kellele saadeti ülikoolide kesksete meilisüsteemide kaudu e-kirjad palvega uuringus osaleda. Peale küsimustikuni viiva veebilingi sisaldas e-kiri uuringus osalemise vabatahtlikkuse ja vastajate anonüümsuse tagamise põhimõtteid. Juhuslikku valimisse kuulus 380 üliõpilast, kellest 243 olid bakalaureusetaseme üliõpilased ja 137 magistritaseme üliópilased. Vastanutest 102 (27\%) õppisid humanitaarteaduste ja kunstide valdkonnas, 91 (24\%) loodus- ja täppisteaduste valdkonnas, 50 (13\%) meditsiiniteaduste valdkonnas ning 137 (36\%) sotsiaalteaduste valdkonnas. 26\% (99) vastajatest oli mees- ja 74\% (281) naissoost.

Andmeid koguti Helsingi Ülikoolis välja töötatud küsimustikuga (vt Löfström et al., 2017), millega mõõdeti üliõpilaste subjektiivseid hinnanguid 
oma teadmistele plagiaadist ja plagiaadituvastussüsteemidest. Originaalküsimustikku kohandati Eesti üliõpilaste jaoks, sh tõlgiti küsimustik inglise keelest eesti keelde ning lisati seosed Eesti kontekstiga. Valiidsuse tagamiseks tõlkis kolmas isik küsimustiku tagasi inglise keelde ja võrdles originaali uue ingliskeelse versiooniga. Loodud küsimustik sisaldab väiteid, mida hinnatakse viiepunktisel Likerti skaalal, ning valikvastustega ja avatud küsimusi. Küsimustik koosneb järgmistest teemaplokkidest: sissejuhatav osa vastajate taustandmete (soo, valdkonna, õppeastme) kohta, küsimused plagiaadi leviku, selle esinemise põhjuste, plagiaadivormide tundmise ja plagiaadi tagajärgede kohta ning küsimused plagiaadituvastussüsteemide ja nende plagiaadivastaste kasutusvõimaluste kohta. Lisaks oli küsitluses osalenutel võimalik selgitada oma vastuseid avatud küsimuste formaadis (nt „Kuidas saaks Teie arvates plagiaadituvastussüsteeme kasutada, et toetada üliõpilasi nende õpingutes?"). Kvantitatiivselt analüüsitavad vastused olid kas nominaal- (õppetase, valdkond, sugu) või järjestusskaalal (kõik ülejäänud).

\section{Andmeanalüïs}

Andmeanalüüsiks kasutati SPSS 20.0 programmi. Kuna gruppides ei saa vastustel eeldada normaaljaotust, selgitati gruppidevahelisi erinevusi MannWhitney U-testiga (sugu ning bakalaureuse- ja magistritase) või KruskalWallise ühesuunalise ANOVA testiga (neli teadusvaldkonda) (vt McCrumGardner, 2008). Normaaljaotuse eelduse puudumisel ei arvutatud Coheni $d$ statistikut. Erinevused loeti statistiliselt oluliseks, kui $p<0,05$. Plagieerimise põhjuste uurimiseks tehti uuriv faktoranalüüs peatelgede meetodil koos varimax-pööramisega. Selle tulemusena eristus kolm faktorit, mille alla laadusid kõik küsimustiku väited. Faktorite sisereliaablust kontrolliti Cronbachi alfaga $(\alpha \geq 0,70)$ (vt Costello \& Osborne, 2005).

Avatud küsimuste vastuseid analüüsiti kvalitatiivse induktiivse sisuanalüüsi meetodil (Vaismoradi, Turunen, \& Bondas, 2013, lk 401-402). Esmalt kanti andmed tabelisse, kuhu koondati küsimuste kaupa kõigi üliõpilaste vastused. Seejärel otsiti üliõpilaste vastustest küsimuse seisukohast tähenduslikke tekstiosi, millele anti sobiv kood. Pärast andmete kodeerimist koondati sarnase sisuga koodid vastavasse kategooriasse. Vastustes, mis sisaldasid eri teemasid, eristati kõigepealt teemad ning seejärel jaotati need sisu alusel sobivate kategooriate alla. Andmeid analüüsisid paralleelselt kaks uurijat, kes kõrvutasid saadud tulemusi omavahel. Kategooriate võrdlemisel selgus, et erinevusi esines väga vähesel määral. Erinevuste korral mindi tagasi algandmete juurde ja arutleti teemade üle konsensuse saavutamiseni. Kodeerijatevaheline kooskõla oli üle $98 \%$. 


\section{Tulemused}

\section{Üliõpilaste hoiakud plagiaadi ja plagieerimispõhjuste kohta}

Esmalt selgitati, kui levinud probleemiks üliõpilased plagiaati peavad. Tulemustest ilmnes, et 26\% bakalaureusetaseme ja 21,9\% magistritaseme üliõpilastest hindab plagiaati levinud probleemiks. Esile tõusid ka soopõhised erinevused: mehed $(30,3 \%)$ peavad plagiaati oluliselt levinumaks kui naised $(22,4 \%)(U=12230,5, p=0,045)$. Teadusvaldkonniti statistiliselt olulisi erinevusi polnud.

Järgnevalt analüüsiti, kui oluliseks hindavad üliõpilased erinevaid plagieerimispõhjusi. Põhjuste struktureerimiseks kasutati faktoranalüüsi, mille tulemusel eristus kolm faktorit omaväärtusega üle 1 (vt tabel 2) (Costello \& Osborne, 2005).

Tabel 1. Üliõpilaste plagieerimispõhjuste jagunemine kolme faktori vahel

\begin{tabular}{|c|c|c|c|}
\hline Põhjus & Faktor 1 & Faktor 2 & Faktor 3 \\
\hline 1. Üliõpilased ei leia, et plagieerimine on ränk eksimus. & 0,706 & & \\
\hline $\begin{array}{l}\text { 2. Üliõpilased plagieerivad, kuna nende eakaaslased } \\
\text { teevad seda. }\end{array}$ & 0,721 & & \\
\hline $\begin{array}{l}\text { 3. Üliõpilased plagieerivad, kuna nende kogemuste } \\
\text { põhjal on vahelejäämise risk väiksem kui saadud kasu. }\end{array}$ & 0,786 & & \\
\hline $\begin{array}{l}\text { 4. Plagiaadiga vahelejäämisel on tagajärjed ja karistused } \\
\text { tühised. }\end{array}$ & 0,779 & & \\
\hline $\begin{array}{l}\text { 5. Üliõpilased on üle koormatud liiga paljude kirjalike } \\
\text { töödega ja neil pole piisavalt aega nende korrektseks } \\
\text { tegemiseks. }\end{array}$ & & 0,915 & \\
\hline $\begin{array}{l}\text { 6. Üliõpilastel on elus muid kohustusi, nt perekond või } \\
\text { töö, mis takistavad neil kõikidele õppeülesannetele } \\
\text { korralikult keskendumast. }\end{array}$ & & 0,933 & \\
\hline $\begin{array}{l}\text { 7. Üliõpilased põhimõtteliselt teavad, kuidas kirjutada } \\
\text { akadeemilisi tekste, aga neil pole piisavalt oskusi, et } \\
\text { seda täiesti õigesti teha, nt oma sõnadega kirjutamine. }\end{array}$ & & & 0,831 \\
\hline $\begin{array}{l}\text { 8. Üliõpilased ei tea, kuidas allikaid õigesti kasutada ja } \\
\text { kuidas neile korrektselt viidata. }\end{array}$ & & & 0,845 \\
\hline
\end{tabular}


Esimese faktori moodustasid põhjused, mille tulemusel esitatakse plagiaati teadlikult ning kasu saamise eesmärgil (vt tabel 1, põhjused 1-4). Esimene faktor liigitati tahtlikuks plagiaadiks $(\alpha=0,75)$ ning see seletab ära $28 \%$ kogu põhjuste variatiivsusest. Teise faktori alla koondusid põhjused, mis olid küll loomult tahtlikud, ent tulenesid halvast ajaplaneerimisoskusest või üliõpilaste ülekoormatusest (vt tabel 1, põhjused 5-6). Teine faktor liigitati koormusest tingitud plagiaadiks $(\alpha=0,85)$ ning see seletab ära $22 \%$ kogu põhjuste variatiivsusest. Kolmanda faktori moodustasid põhjused, mis olid seotud üliõpilaste vähese akadeemiliste tekstide kirjutamise oskusega (vt tabel 1, põhjused 7-8). Kolmas faktor liigitati tahtmatuks plagiaadiks $(\alpha=0,71)$ ning see seletab ära $20 \%$ kogu põhjuste variatiivsusest. Kokku seletavad kõik kolm faktorit ära 70\% kogu põhjuste variatiivsusest, mis näitab, et tegemist on suhteliselt hea mudeliga (Costello \& Osborne, 2005).

Gruppidevaheliste erinevuste selgitamiseks moodustati faktoranalüüsist ilmnenud faktorite all olevate alapõhjustega sagedustabelid ning analüüsiti nendevahelisi erinevusi. Sagedustabelitest selgus, et nii bakalaureusetaseme üliõpilased (71\%) kui ka magistritaseme üliõpilased $(71,2 \%)$ peavad kõige olulisemaks põhjusi, mis on seotud tahtmatu plagiaadiga. Kõige suurem erinevus bakalaureuse- ja magistritaseme üliõpilaste arvamustes puudutas tahtliku plagiaadi all esitatud põhjusi: 32,1\% magistritaseme üliõpilastest ja 26,6\% bakalaureusetaseme üliõpilastest pidasid neid oluliseks. Koormusest tingitud põhjusi pidasid magistri- $(55,8 \%)$ ja bakalaureusetaseme $(55,6 \%)$ üliõpilased võrdselt tähtsaks ning statistiliselt olulisi erinevusi eri õppetasemete üliõpilaste arvamustes ei täheldatud.

Hinnangud tahtmatu plagiaadi põhjuste olulisuse kohta (vt tabel 1) erinesid valdkonniti märkimisväärselt (põhjus $7, \chi^{2}(3)=15,246, p=0,002$, põhjus 8 , $\left.\chi^{2}(3)=8,825, p=0,032\right)$. Meditsiiniteaduste $(70 \%)$, sotsiaalteaduste $(74,4 \%)$ ning humanitaarteaduste ja kunstide valdkonna üliõpilased (75\%) hindasid tahtmatu plagiaadi põhjusi võrdväärselt oluliseks, ent loodus- ja täppisteaduste üliõpilaste hulgas oli neid vähem $(62,1 \%)$.

Meeste ja naiste arvamustes esines kõige suurem erinevus hinnangutes, mis anti tahtmatu plagiaadi põhjuste olulisusele. Kui naistest pidas neid põhjusi oluliseks $71,2 \%$, siis meestest pidas neid oluliseks $62,1 \%$ (põhjus $7, U=$ $10921,5, p=0,001$, põhjus $8, U=11569,5, p=0,008$ ). Naiste ja meeste arvamustes statistiliselt olulisi erinevusi esimese (tahtliku plagiaadi) ja teise (koormusest tingitud plagiaadi) faktori põhjustes ei täheldatud.

Järgnevalt analüüsiti üliõpilaste hinnanguid erinevate plagiaadivormide tõsiduse kohta. Kõige tõsisemaks plagiaadivormiks pidasid üliõpilased (99,5\%) teise üliõpilase terviktöö enda omana esitamist. Enim tekitas üliõpilastes 
segadust plagiaadivorm „Sõnasõnaline võõra teksti kasutamine koos viitega originaalautorile, ent ilma jutumärkideta“. 3,7\% üliõpilastest ei teadnud, kas kirjeldatud juhtumi puhul on tegu plagiaadiga või mitte. Enamik üliõpilastest $(45,3 \%)$ arvas, et see on plagiaat, aga mitte tõsine vorm, ning $24,7 \%$ üliõpilastest pidas seda tõsiseks plagiaadivormiks. Märkimist väärib aga see, et arvestatav osa uuringus osalenud üliõpilastest $(26,3 \%)$ ei pidanud seda üldse plagiaadiks.

Järgmises analüüsietapis selgitati välja, kas üliõpilaste hinnangud plagiaadivormide tõsidusele erinevad õppevaldkonniti (vt tabel 2). Kõige enam üliõpilasi, kes ei osanud eri plagiaadivorme ega nende tõsidust hinnata, oli meditsiinivaldkonnas. Sellised plagiaadivormid nagu teise üliõpilase töö esitamine enda omana, kui on olemas teise üliõpilase luba (4\%), sõnasõnaline võõra teksti kasutamine koos viitega originaalautorile, ent ilma jutumärkideta (4\%) ja sõnasõnaline võõra teksti kasutamine koos viitega originaalautorile, kasutades jutumärke (6\%), jäid meditsiiniteaduste üliõpilastele segaseks. Kõige rangemalt (tõsisteks või väga tõsisteks) hindasid eri plagiaadivorme sotsiaalteaduste ning humanitaarteaduste ja kunstide valdkonna üliõpilased ning kõige leebemalt loodus- ja täppisteaduste üliõpilased. Kõige rohkem erinesid üliõpilaste arvamused plagiaadivormi „Sõnasõnaline võora teksti kasutamine koos viitega originaalautorile, ent ilma jutumärkideta" puhul $\left(\chi^{2}(3)=35,357, p<0,001\right)$. Kui meditsiini-, sotsiaal- ning humanitaarteaduste ja kunstide üliõpilased hindasid seda suhteliselt sarnaselt (vastavalt 28\%,27\% ja 33,3\%) tõsiseks plagiaadivormiks, siis 50,5\% loodus- ja täppisteaduste üliõpilastest ei pidanud seda üldse plagiaadiks. Üliõpilaste õppetasemete puhul statistiliselt olulisi erinevusi ei täheldatud.

Meeste ja naiste arvamused erinesid oluliselt kahe plagiaadivormi puhul. Plagiaadivormi „Võõra(ste) autori(te) teksti enda omana esitamine ilma allikale viitamata" pidas tõsiseks $78,8 \%$ meestest ja 89,3\% naistest ( $U=9989,5$, $p<0,001)$. Seevastu plagiaadivormi „sõnasõnaline võõra teksti kasutamine koos viitega originaalautorile, ent ilma jutumärkideta" hindas tõsiseks 16,2\% meestest ja $27,7 \%$ naistest $(U=10426,5, p<0,001$ ). 
Tabel 2. Üliõpilaste arvamused (esitatud protsentides) eri plagiaadivormide tõsiduse kohta õppevaldkonniti

\begin{tabular}{|c|c|c|c|c|c|c|c|c|}
\hline & \multicolumn{4}{|c|}{ Meditsiiniteadused $(n=50)$} & \multicolumn{4}{|c|}{ Sotsiaalteadused $(n=137)$} \\
\hline & $\begin{array}{c}\text { Ei } \\
\text { tea }\end{array}$ & $\begin{array}{c}\text { Pole } \\
\text { pla- } \\
\text { giaat }\end{array}$ & $\begin{array}{l}\text { Plagiaat, } \\
\text { aga } \\
\text { mitte } \\
\text { tõsine } \\
\text { plagiaadi- } \\
\text { vorm }\end{array}$ & $\begin{array}{c}\text { Mõnevõrra } \\
\text { tõsisem ja } \\
\text { väga } \\
\text { tõsine } \\
\text { plagiaadi- } \\
\text { vorm }\end{array}$ & $\begin{array}{c}\text { Ei } \\
\text { tea }\end{array}$ & $\begin{array}{l}\text { Pole } \\
\text { pla- } \\
\text { giaat }\end{array}$ & $\begin{array}{l}\text { Plagiaat, } \\
\text { aga } \\
\text { mitte } \\
\text { tõsine } \\
\text { plagiaadi- } \\
\text { vorm }\end{array}$ & $\begin{array}{l}\text { Mõnevõrra } \\
\text { tõsisem ja } \\
\text { väga } \\
\text { tõsine } \\
\text { plagiaadi- } \\
\text { vorm }\end{array}$ \\
\hline $\begin{array}{l}\text { 1. Teise üliõpilase } \\
\text { töö osade enda } \\
\text { omana esitamine }\end{array}$ & & 2 & 26 & 72 & & & 10,2 & 89,8 \\
\hline $\begin{array}{l}\text { 2. Teise üliõpilase } \\
\text { terve töö enda } \\
\text { omana esitamine }\end{array}$ & & & & 100 & & & 1,5 & 98,5 \\
\hline $\begin{array}{l}\text { 3. Teise üliõpilase } \\
\text { töö enda omana } \\
\text { esitamine, kui on } \\
\text { olemas teise } \\
\text { üliõpilase luba }\end{array}$ & 4 & 18 & 14 & 64 & & 2,9 & 14,6 & 82,5 \\
\hline $\begin{array}{l}\text { 4. Võõra(ste) } \\
\text { autori(te) teksti } \\
\text { enda omana } \\
\text { esitamine ilma } \\
\text { allikale viitamata }\end{array}$ & & 4 & 8 & 88 & & 0,7 & 10,2 & 89,1 \\
\hline $\begin{array}{l}\text { 5. Sõnasõnaline } \\
\text { võõra teksti } \\
\text { kasutamine } \\
\text { koos viitega } \\
\text { originaalautorile, } \\
\text { ent ilma } \\
\text { jutumärkideta }\end{array}$ & 4 & 34 & 34 & 28 & 2,2 & 14,6 & 56,2 & 27,0 \\
\hline $\begin{array}{l}\text { 6. Sõnasõnaline } \\
\text { võõra teksti } \\
\text { kasutamine } \\
\text { koos viitega } \\
\text { originaalautorile, } \\
\text { kasutades } \\
\text { jutumärke }\end{array}$ & 6 & 80 & 6 & 8 & 3,6 & 83,2 & 5,2 & 8,0 \\
\hline
\end{tabular}




\begin{tabular}{|c|c|c|c|c|c|c|c|c|}
\hline & \multicolumn{4}{|c|}{$\begin{array}{l}\text { Humanitaarteadused ja kunstid } \\
\qquad(n=102)\end{array}$} & \multicolumn{4}{|c|}{$\begin{array}{l}\text { Loodus- ja täppisteadused } \\
\qquad(n=91)\end{array}$} \\
\hline & $\begin{array}{c}\mathrm{Ei} \\
\text { tea }\end{array}$ & $\begin{array}{l}\text { Pole } \\
\text { pla- } \\
\text { giaat }\end{array}$ & $\begin{array}{l}\text { Plagiaat, } \\
\text { aga } \\
\text { mitte } \\
\text { tõsine } \\
\text { plagiaadi- } \\
\text { vorm }\end{array}$ & $\begin{array}{l}\text { Mõnevõrra } \\
\text { tõsisem } \\
\text { ja väga } \\
\text { tõsine } \\
\text { plagiaadi- } \\
\text { vorm }\end{array}$ & $\begin{array}{l}\text { Ei } \\
\text { tea }\end{array}$ & $\begin{array}{l}\text { Pole } \\
\text { pla- } \\
\text { giaat }\end{array}$ & $\begin{array}{l}\text { Plagiaat, } \\
\text { aga } \\
\text { mitte } \\
\text { tõsine } \\
\text { plagiaadi- } \\
\text { vorm }\end{array}$ & $\begin{array}{l}\text { Mõnevõrra } \\
\text { tõsisem } \\
\text { ja väga } \\
\text { tõsine } \\
\text { plagiaadi- } \\
\text { vorm }\end{array}$ \\
\hline $\begin{array}{l}\text { 1. Teise üliõpilase } \\
\text { töö osade enda } \\
\text { omana esitamine }\end{array}$ & & & 17,6 & 82,4 & & 1,1 & 24,2 & 74,7 \\
\hline $\begin{array}{l}\text { 2. Teise üliõpilase } \\
\text { terve töö enda } \\
\text { omana } \\
\text { esitamine }\end{array}$ & & & & 100 & & & & 100 \\
\hline $\begin{array}{l}\text { 3. Teise üliõpilase } \\
\text { töö enda omana } \\
\text { esitamine, kui } \\
\text { on olemas teise } \\
\text { üliõpilase luba }\end{array}$ & 3,9 & 4,9 & 19,6 & 71,6 & 2,2 & 7,7 & 15,3 & 74,8 \\
\hline $\begin{array}{l}\text { 4. Võõra(ste) } \\
\text { autori(te) teksti } \\
\text { enda omana } \\
\text { esitamine ilma } \\
\text { allikale viitamata }\end{array}$ & & 1 & 9,8 & 89,2 & & 2,2 & 18,7 & 79,1 \\
\hline $\begin{array}{l}\text { 5. Sõnasõnaline } \\
\text { võõra teksti } \\
\text { kasutamine koos } \\
\text { viitega originaal- } \\
\text { autorile, ent ilma } \\
\text { jutumärkideta }\end{array}$ & 4,9 & 16,7 & 45,1 & 33,3 & 4,4 & 50,5 & 35,2 & 9,9 \\
\hline $\begin{array}{l}\text { 6. Sõnasõnaline } \\
\text { võõra teksti } \\
\text { kasutamine koos } \\
\text { viitega originaal- } \\
\text { autorile, kasu- } \\
\text { tades jutumärke }\end{array}$ & 2,9 & 86,4 & 2,9 & 7,8 & 3,3 & 94,5 & 1,1 & 1,1 \\
\hline
\end{tabular}




\section{Üliõpilaste teadlikkus plagiaadi tagajärgedest}

$36,3 \%$ uuringus osalenud üliõpilastest hindas oma teadlikkust plagiaadi tagajärgedest heaks või väga heaks. Seevastu 37,6\% üliõpilastest leidis, et nad ei ole üldse kursis või on halvasti kursis sellega, mis juhtub üliõpilasega, kelle tööst on leitud plagiaati. Erinevused üliõpilaste arvamustes ilmnesid ka valdkondade vahel $\left(\chi^{2}(3)=14,212, p=0,003\right)$. Oma teadmisi plagiaadi tagajärgedest hindasid kõige paremaks loodus- ja täppisteaduste üliõpilased (37,7\%), neile järgnesid sotsiaalteaduste $(35,7 \%)$, humanitaarteaduste ja kunstide $(31,7 \%)$ ning lõpuks meditsiiniteaduste üliõpilased (31\%). Õppetasemete vahel üliõpilaste arvamustes olulisi erinevusi polnud.

Kvalitatiivse sisuanalüüsi tulemused näitasid, et üliõpilased pidasid plagiaadi tagajärjeks eksmatrikuleerimist. Samuti arvati, et karistused võivad sõltuda eri teguritest, nagu plagiaadi raskusaste, õppejõu rangus.

Kõige leebemal juhul kutsutakse kohvile ja räägitakse plagiaadi halbadest külgedest (nii juhtus mitme minu kursakaaslasega ühes aines kunagi bakas) ning kõige rängemal juhul visatakse ülikoolist välja. (Üliõpilane A)

Peale selle juhtisid üliõpilased oma vastustes tähelepanu karistuste tegelikule puudumisele või ettenähtust oluliselt leebematele karistustele.

Meil on saadetud prodekaanile juhtum, aga sealt on näinud ainult hoiatust, kui sedagi. (Üliõpilane B)

Teoorias peaks üliõpilane minema esmalt vestlusele, et selgitada välja, miks üliõpilane nii tegi ja selgitada kui tõsine asi see on. Karmim tagajärg on eksmatrikuleerimine. Reaalsuses olen ühe õpilase plagiaadi kohta õppejõule märku andnud. Projekti osa oli sõna-sõnalt kopeeritud kaasõpilaste tööst, lisaks veel kogu töö struktuur. Tagajärjeks oli see, et see üliõpilane pidi lihtsalt oma töö ümber tegema. (Üliõpilane C)

Üliõpilased nimetasid ka mitmesuguseid põhjusi, miks nad ei ole plagiaadi olemusest teadlikud. Põhjustena toodi, et seda teemat käsitletakse õppetöös vähe või ei käsitleta üldse, samas märgiti soovi sellest rohkem kuulda.

Otseselt pole keegi rääkinud sellel teemal. (Üliõpilane D)

Ma pole ülikoolis kuulnud õppejõude sellest rääkivat, et mis karistus järgneb plagieerimisele. Ma sooviksin küll teada, mis juhtub. (Üliõpilane E)

Uuringu tulemustest ilmnes, et 97,1\% sotsiaalteaduste valdkonna ning humanitaarteaduste ja kunstide valdkonna üliõpilastest on oma õpingute jooksul kokku puutunud allikate kasutamise teemaga, samas kui loodus- ja täppis- 
teaduste valdkonnas oli allikate kasutamisest enda sõnul kuulnud 76,9\% uuringus osalenud üliõpilastest ning meditsiiniteaduste valdkonnas vaid $66 \%$ uuringus osalenud üliõpilastest. Ka akadeemiliste tekstide kirjutamisega on sotsiaalteaduste $(85,4 \%)$ ning humanitaarteaduste ja kunstide $(88,2 \%)$ valdkonna üliõpilased rohkem tuttavad kui loodus- ja täppisteaduste $(60,4 \%)$ ning meditsiiniteaduste (40\%) üliõpilased $\left(\chi^{2}(3)=38,286, p<0,001\right)$. Õppetasemete võrdluses on magistritaseme üliõpilased (94,2\%) allikate kasutamise teemaga rohkem kokku puutunud kui bakalaureusetaseme üliõpilased $(85,2 \%)$ $(U=15192,5, p=0,011)$.

\section{Üliõpilaste arvamused plagiaadituvastussüsteemidest}

Tulemustest ilmnes, et magistritaseme üliõpilased (28,5\%) on oluliselt rohkem plagiaadituvastussüsteeme kasutanud kui bakalaureusetaseme üliõpilased $(14,4 \%)(U=14304,5, p=0,001)$. Samuti on naised $(22,4 \%)$ märksa rohkem kasutanud plagiaadituvastussüsteeme kui mehed (11,1\%) $(U=12336,5$, $p=0,015)$. Kõige enam on kasutatud plagiaadituvastussüsteeme Kratt $(n=34)$ ja Urkund $(n=22)$. Peale nimetatute on üliõpilased vähesel määral kasutanud Turnitini, Plagscani, Quetexti, Estplagi ja Grammarlyt.

Andmeanalüüsist ilmnes, et üliõpilastel on seoses plagiaadituvastussüsteemidega mitmesuguseid hirme. Näiteks tekib küsimus, mis juhtub siis, kui süsteem tuvastab plagiaadi, kuigi tegelikult plagiaadiga tegemist ei ole, ning selle alusel võidakse karistada.

Võivad esineda vale-positiivsed tulemused, ja tudeng ei saa tõestada vastupidist. (Üliõpilane F).

Mitu üliõpilast leidis, et plagiaadituvastussüsteemidest võiks olla kasu, kui üliõpilased saaksid neid õppeprotsessis iseseisvalt kasutada (ka koos õppejõuga). Lisaks võiksid õppejõud teavitada üliõpilasi plagiaadituvastussüsteemide olemasolust ning tutvustada nende toimimise põhimõtteid ja kasutamise tingimusi.

Ma ei tea ühtegi plagiaadituvastussüsteemi, mida saaksin kasutada tasuta. Muidugi ise pole ka huvi tundnud. Kui need oleksid populaarsed, siis ei tekitaks see nii palju hirmu, sest ise saad ka kontrollida ja näed, mida süsteem teeb. Samuti kasulik alguses, kui ei oska veel nii hästi näiteks refereerida. (Üliõpilane G)

Peaks kooskõlastama üliõpilastega, et sellist programmi kasutatakse (seda minu kogemuse järgi ei ole tehtud) ning selgitama, miks on plagiaat just akadeemilises kontekstis tõsine teema (mitte stiilis „plagiaat on halb, sest nii ei tehta ja see on ebaaus" nagu siiani on ainetes tehtud) (Üliõpilane $\mathrm{H}$ ) 
Plagiaadituvastussüsteemide kohustuslikku kasutamist pidas õigeks 54,5\% uuringus osalenud üliõpilastest, sh 56,2\% naistest ja 49,5\% meestest. Üliõpilased leidsid, et plagiaadituvastussüsteemidega peaks kontrollima suuremahulisi töid, nagu bakalaureuse-, magistri- ja doktoritööd.

\section{Arutelu}

Artikli aluseks olev uuring on Eestis üks esimesi, mille eesmärk on välja selgitada üliópilaste arusaamad plagiaadist ja plagiaadituvastussüsteemide kasutamisest. Uurimistulemused pakuvad uusi teadmisi võimalike raskuste kohta, millega õppejõud peavad arvestama üliõpilastele kirjalikke töid andes. Samuti osutavad need võimalikele viisidele, kuidas arendada akadeemiliste tekstide kirjutamise kultuuri ülikoolis.

Üliõpilaste arvamused plagiaadist ja selle esinemise põhjustest osutusid sarnaseks varasemate uuringute tulemustega (nt Chen \& Chou, 2017; Löfström \& Kupila, 2013; Pickard, 2006), mille kohaselt peeti plagiaati küll suureks probleemiks, ent siiski ei teadnud enamik uuringus osalenud üliõpilasi, kui levinud plagiaat on. Üks põhjustest, miks üliõpilased ei osanud plagiaadi leviku ulatust hinnata, võib olla see, et plagiaadijuhtumid pole avalikud ning seetõttu ei olda neist enamasti ka teadlikud. Nii Helsingi Ülikoolis (vt Löfström et al., 2017) tehtud kui ka praegusest uuringust ilmnes, et üliópilaste plagieerimiskäitumise põhjal võib eristada kolme tüüpi plagiaati: tahtlikku, tahtmatut ja koormusest tingitud plagiaati. Uuringus osalenud üliópilased leidsid, et kõige enam esineb üliõpilastöödes tahtmatut plagiaati, mis osutab väga tähtsale pedagoogiliseetilisele dilemmale: üliõpilased peavad plagiaati küll lubamatuks, ent samas pole nad kindlad, kas nad teavad, milles plagiaat täpsemalt seisneb ning kuidas sellest oma kirjalikes töödes hoiduda. Siit tõstatub oluline teema kõigi nende õppejõudude jaoks, kes peaksid oma õpetatava aine raames peale aine sisu edasiandmise tutvustama üliõpilastele ka akadeemilist kultuuri ja selles kehtivaid tavasid.

Suured erinevused üliõpilaste teadmistes plagiaadivormide kohta ilmnesid teadusvaldkonniti. Sotsiaalteaduste ning humanitaarteaduste ja kunstide valdkonna üliõpilaste teadmised osutusid siinkohal paremaks meditsiiniteaduste ning loodus- ja täppisteaduste valdkonna üliõpilaste omadest. Samuti hindasid teemaga paremini kursis olevate valdkondade üliõpilased rangemalt eri plagiaadivorme. Samale tulemusele on jõutud ka varasemates uuringutes (Bokosmaty et al., 2017; Chen \& Chou, 2017). Valdkondadevaheliste erinevuste põhjus võib olla seisukoht, et igal teadusharul on oma spetsifika ning seetõttu erinev arusaam plagiaadist. See omakorda viitab vajadusele kujun- 
dada institutsioonides ühtsed arusaamad plagiaadi olemusest ning pakkuda ka õppejõududele selle kohta koolitusi. Lisaks tekitab uuringu tulemusi analüüsides küsimusi üliõpilaste vähene teadlikkus plagiaadi avastamisega kaasnevatest võimalikest tagajärgedest, mida on omakorda peetud oluliseks teguriks plagiaadiga võitlemisel (vt nt Gullifer \& Tyson, 2014). Tulemused näitavad, et vähem kui pooled uuringus osalenud üliõpilastest hindavad oma teadmisi heaks, mis osutab vajadusele pöörata senisest märksa enam tähelepanu, kuidas suurendada üliõpilaste teadlikkust plagiaadist kui ebaausast ja mitteaktsepteeritud käitumisest.

Üliõpilaste arusaamad plagiaadist ja selle tagajärgedest ei erinenud oluliselt õppetasemeti. Magistritaseme üliõpilased olid küll plagiaadist veidi rohkem teadlikud ning suhtusid plagiaadiprobleemi ka rangemalt, mis on nende suurema kogemuse tõttu ka loomulik, ent erinevused olid siiski väheolulised. Vähesel määral esines erinevusi ka meeste ja naiste arvamustes, ent kuna meeste ja naiste osakaal ei olnud kõigis valdkondades proportsionaalne, siis võisid need tuleneda valdkondlikest erinevustest. Siiski on varasemates uuringutes leitud, et naised on plagiaadist enamasti teadlikumad ja nende hoiakud plagiaadi suhtes on üldjuhul negatiivsemad, samas kui meeste teadlikkus on olnud väiksem ning nad on ka enam olnud valmis riskeerima ja reegleid rikkuma (Jereb, Urh, Jerebic, \& Šprajc, 2018).

Plagiaadituvastussüsteemidel on kahtlemata oma koht plagiaadi leviku piiramisel, mistõttu tuleks neid üliõpilastele rohkem tutvustada. Samuti peaksid õppejõud suunama üliõpilasi oma töid ise kontrollima. Probleemiks plagiaadituvastussüsteemide vabal kasutamisel võib kujuneda aga see, et üliõpilased hakkavad nende abil plagiaati peitma. Samas pole seni leitud ühtegi tõendit selle kohta, et üliõpilased kasutaksid plagiaadituvastussüsteeme vaid õppetöös lihtsama läbisaamise eesmärgil (vt Chew et al., 2015). Lisaks selgus uuringust, et üliõpilased pidasid vajalikumaks plagiaadituvastussüsteemi abil kontrollida eri õppetasemete lõputöid, mitte niivõrd oma väiksemamahulisi kirjalikke töid. Sellest nähtub, et üliõpilased peavad teatud kirjalikke töid ülikoolis olulisemaks ning see justkui õigustaks nende arvates eksimisi vähem tähtsates töödes.

Akadeemiliste tekstide kirjutamisega tuleb üliõpilastel kokku puutuda juba õpingute alguses ning kirjutamisel on oluline roll kogu õpingute vältel. See omakorda osutab vajadusele pakkuda üliõpilastele juba õpingute alguses põhiteadmisi akadeemiliste tekstide kirjutamise põhitõdede kohta. Kui õppejõud saavad aru, mis probleemidega üliõpilased akadeemiliste tekstide kirjutamisel kokku puutuvad, saab kasutada tõhusamaid toetusmeetmeid. Ka uuringu tulemused näitavad, et üliõpilased vajavad õppejõudude toetust, et paremini mõista, kuidas kasutatud allikatele õigesti viidata. 
Varasemates uurimustes on juhitud tähelepanu võimalikele tagajärgedele, mis võivad esile tulla olukorras, kus akadeemiliste tekstide kirjutamise õpetamisel esinevad puudujäägid. Näiteks võib hirm plagiaadi ja plagiaadituvastussüsteemide kasutamise ees üliõpilaste õppimist negatiivselt mõjutada. Emotsioonide olulisust õppimisel on rõhutatud ka varasemates uurimustes (vt nt Linnenbrink-Garcia \& Pekrun, 2011). Kuna kirjutamine on ülikooliõpingutes tähtsal kohal, siis on üliõpilaste toetamisel vaja silmas pidada, et neile ei seostuks kirjutamine vaid negatiivsete tunnete ja hirmuga, mis võib omakorda takistada õpingutesse süvenemist. Niisamuti tuleks ülikoolides vältida olukordi, kus keskendutakse vaid plagiaadi tagajärgedele ja eksinute karistamisele. Ülikoolidel peaksid küll olemas olema nii juhendid kui ka protseduurid selle kohta, kuidas plagiaadikahtlustuse korral käituda, ent ennetustöö tõhustamine aitaks pöörata fookuse sellele, kuidas paremini toetada üliõpilaste õppimist. Samas on tähtis, et ülikoolid toetaksid ka õppejõude, pakkudes neile koolitusi ja võimalusi vahetada kogemusi selle kohta, kuidas juhendada üliõpilasi akadeemiliste tekstide kirjutamise heade tavade järgimisel ning suurendada nende teadlikkust intellektuaalse omandi kaitsmisel (Chen \& Chou, 2017). Ennetustöö kaudu saaks seada rõhuasetuse õpioskustele ja paremale ajakasutusoskusele ning pakkuda üliõpilastele tuge, et nad saaksid oma kirjutamisoskusi pingevabalt arendada.

Uurimuse piiranguks on võrreldavate rühmade väike osakaal ja ebaühtlane jaotus. Lisaks piirab järjestusskaala kasutus statistiliste järelduste tegemist, kuna uuritavad võivad erinevalt aru saada, mida „väga oluline“ tähendab (Risquez, O’Dwyer, \& Ledwith, 2013). Järgmistes uuringutes võiks olla rohkem küsimusi vahemik- ja suhteskaaladel. Näiteks võiks konkreetsemalt uurida, kui palju on plagiaadituvastussüsteeme kasutatud („Mitu korda oled tööd üles laadinud?"). Peale üliõpilaste arusaamade on tähtis mõista ka teiste õppeprotsessi osaliste ehk õppejõudude arusaamu plagiaadist ja plagiaadituvastussüsteemidest, sest nagu ka praeguse uuringu tulemused osutavad, peavad üliõpilased õppejõudude tegevust plagiaadiga seonduva teadvustamisel ja akadeemiliste tekstide kirjutamise oskuse arendamisel väga väärtuslikuks.

\section{Kasutatud kirjandus}

Adam, L., Anderson, A., \& Spronken-Smith, R. (2017). 'It's not fair': Policy discourses and students' understandings of plagiarism in a New Zealand university. Higher Education, 74(1), 17-32. https://doi.org/10.1007/s10734-016-0025-9

Babaii, E., \& Nejadghanbar, H. (2017). Plagiarism among Iranian graduate students of language studies: Perspectives and causes. Ethics \& Behavior, 27(3), 240-258. https://doi.org/10.1080/10508422.2016.1138864 
Bokosmaty, S., Ehrich, J., Eady, M. J., \& Bell, K. (2017). Canadian university students' gendered attitudes toward plagiarism. Journal of Further and Higher Education, 43(2), 276-290. https://doi.org/10.1080/0309877X.2017.1359505

Bruton, S., \& Childers, D. (2016). The ethics and politics of policing plagiarism: A qualitative study of faculty views on student plagiarism and Turnitin ${ }^{\oplus}$. Assessment \& Evaluation in Higher Education, 41(2), 316-330. https://doi.org/10.1080/02602938.2015.1008981

Chankova, M. (2017). Dealing with students' plagiarism pre-emptively through teaching proper information exploitation. International Journal for the Scholarship of Teaching and Learning, 11(2), 1-10. https://doi.org/10.20429/ijsotl.2017.110204

Chen, Y., \& Chou, C. (2017). Are we on the same page? College students' and faculty's perception of student plagiarism in Taiwan. Ethics \& Behavior, 27(1), 53-73. https://doi.org/10.1080/10508422.2015.1123630

Chew, E., Ding, S. L., \& Rowell, G. (2015). Changing attitudes in learning and assessment: Cast-off 'plagiarism detection' and cast-on self-service assessment for learning. Innovations in Education and Teaching International, 52(5), 454-463. https://doi.org/10.1080/14703297.2013.832633

Christensen Hughes, J. M., \& McCabe, D. L. (2006). Understanding academic misconduct. Canadian Journal of Higher Education, 36(1), 49-63.

Costello, A. B., \& Osborne, J. W. (2005). Best practices in exploratory factor analysis: Four recommendations for getting the most from your analysis. Practical Assessment Research \& Evaluation, 10(7), 1-9.

Dhammi, I. K., \& Haq, R. U. (2016). Plagiarism and how to avoid it? Indian Journal of Orthopaedics, 50(6), 581-583. https://doi.org/10.4103/0019-5413.193485

Eckel, E. J. (2011). Textual appropriation in engineering Master's theses: A preliminary study. Science and Engineering Ethics, 17(3), 469-483. https://doi.org/10.1007/s11948-010-9214-6

Eissen, S. M., \& Stein, B. (2006). Intrinsic plagiarism detection. In A. Tombros et al. (Eds.), Proceedings of the 28th European Conference on IR Research (pp. 565-569). Heidelberg: Springer. https://doi.org/10.1007/11735106_66

Eret, E., \& Gokmenoglu, T. (2010). Plagiarism in higher education: A case study with prospective academicians. Procedia - Social and Behavioral Sciences, 2(2), 33033307. https://doi.org/10.1016/j.sbspro.2010.03.505

Espinoza, L. A., \& Nájera, J. M. (2015). How to correct teaching methods that favour plagiarism: Recommendations from teachers and students in a Spanish language distance education university. Assessment \& Evaluation in Higher Education, 40(8), 1070-1078. https://doi.org/10.1080/02602938.2014.966053

Evans, R. (2006). Evaluating an electronic plagiarism detection service. Active Learning in Higher Education, 7(1), 87-99. https://doi.org/10.1177/1469787406061150

Ewing, H., Mathieson, K., Anast, A., \& Roehling, T. (2017). Student and faculty perceptions of plagiarism in health sciences education. Journal of Further and Higher Education, 43(1), 79-88. https://doi.org/10.1080/0309877X.2017.1356913

Ferrero, J., Schwab, D., Besacier, L., \& Agnes, F. (2017). Deep investigation of crosslanguage plagiarism detection methods. Paper presented at the 10th Workshop on Building and Using Comparable Corpora, Vancouver, Canada (pp. 6-15). Retrieved from http://aclweb.org/anthology/W17-25. 
Flint, A., Clegg, S., \& Macdonald, R. (2006). Exploring staff perceptions of student plagiarism. Journal of Further and Higher Education, 30(2), 145-156. https://doi.org/10.1080/03098770600617562

Gullifer, J. M., \& Tyson, G. A. (2014). Who has read the policy on plagiarism? Unpacking students' understanding of plagiarism. Studies in Higher Education, 39(7), 1202-1218. https://doi.org/10.1080/03075079.2013.777412

Hannabuss, S. (2001). Contested texts: Issues of plagiarism. Library Management, 22(6/7), 311-318. https://doi.org/10.1108/EUM0000000005595

Hayes, N., \& Introna, L. D. (2005). Cultural values, plagiarism, and fairness: When plagiarism gets in the way of learning. Ethics \& Behavior, 15(3), 213-231. https://doi.org/10.1207/s15327019eb1503_2

Hensley, L. C., Kirkpatrick, K. M., \& Burgoon, J. M. (2013). Relation of gender, course enrollment, and grades to distinct forms of academic dishonesty. Teaching in Higher Education, 18(8), 895-907. https://doi.org/10.1080/13562517.2013.827641

Honig, B., \& Bedi, A. (2012). The fox in the henhouse: A critical examination of plagiarism among members of the academy of management. Academy of Management Learning \& Education, 11(1), 101-123. https://doi.org/10.5465/amle.2010.0084

Ison, D. C. (2012). Plagiarism among dissertations: Prevalence at online institutions. Journal of Academic Ethics, 10(3), 227-236. https://doi.org/10.1007/s10805-012-9165-4

Iyer, R., \& Eastman, J. K. (2006). Academic dishonesty: Are business students different from other college students? Journal of Education for Business, 82(2), 101-110. https://doi.org/10.3200/JOEB.82.2.101-110

Jereb, E., Urh, M., Jerebic, J., \& Šprajc, P. (2018). Gender differences and the awareness of plagiarism in higher education. Social Psychology of Education, 21(2), 409426. https://doi.org/10.1007/s11218-017-9421-y

Kayaoğlu, M. N., Erbay, Ş., Flitner, C., \& Saltaş, D. (2016). Examining students' perceptions of plagiarism: A cross-cultural study at tertiary level. Journal of Further and Higher Education, 40(5), 682-705. https://doi.org/10.1080/0309877X.2015.1014320

Lagerspetz, M. (2017). Ühiskonna uurimise meetodid. Sissejuhatus ja väljajuhatus. Tallinn: Tallinna Ülikooli Kirjastus.

Linnenbrink-Garcia, L., \& Pekrun, R. (2011). Students' emotions and academic engagement: Introduction to the special issue. Contemporary Educational Psychology, 36(1), 1-3. https://doi.org/10.1016/j.cedpsych.2010.11.004

Löfström, E., Huotari, E., \& Kupila, P. (2017). Conceptions of plagiarism and problems in academic writing in a changing landscape of external regulation. Journal of Academic Ethics, 15(3), 277-292. https://doi.org/10.1007/s10805-017-9285-y

Löfström, E., \& Kupila, P. (2013). The instructional challenges of student plagiarism. Journal of Academic Ethics, 11(3), 231-242. https://doi.org/10.1007/s10805-013-9181-z

Marshall, S., \& Garry, M. (2005). How well do students really understand plagiarism? H. Goss (Ed.), Balance, fidelity, mobility: Maintaining the momentum? Proceedings of the 22nd ASCILITE Conference Brisbane, 4-7 December (pp. 457-467). Retrieved from http://www.ascilite.org/conferences/brisbane05/blogs/proceedings/52_Marshall.pdf. 
McCabe, D. L., Feghali, T., \& Abdallah, H. (2008). Academic dishonesty in the middle east: Individual and contextual factors. Research in Higher Education, 49(5), 451-467. https://doi.org/10.1007/s11162-008-9092-9

McCabe, D. L., \& Trevino, L. K. (1997). Individual and contextual influences on academic dishonesty. Research in Higher Education, 38(3), 379-396. https://doi.org/10.1023/A:1024954224675

McCrum-Gardner, E. (2008). Which is the correct statistical test to use? British Journal of Oral and Maxillofacial Surgery, 46(1), 38-41. https://doi.org/10.1016/j.bjoms.2007.09.002

Moss, S. A., White, B., \& Lee, J. (2018). A systematic review into the psychological causes and correlates of plagiarism. Ethics \& Behavior, 28(4), 261-283. https://doi.org/10.1080/10508422.2017.1341837

Myers, C. S. (2018). Plagiarism and copyright: Best practices for classroom education. College \& Undergraduate Libraries, 25(1), 91-99. https://doi.org/10.1080/10691316.2017.1391028

Pickard, J. (2006). Staff and student attitudes to plagiarism at University College Northampton. Assessment \& Evaluation in Higher Education, 31(2), 215-232. https://doi.org/10.1080/02602930500262528

Risquez, A., O’Dwyer, M., \& Ledwith, A. (2013). 'Thou shalt not plagiarise': From self-reported views to recognition and avoidance of plagiarism. Assessment \& Evaluation in Higher Education, 38(1), 34-43. https://doi.org/10.1080/02602938.2011.596926

Sarwar, M., Moin, M., \& Jabeen, M. (2016). Role of plagiarism detecting software in reducing academic dishonesty at M.Phil level. The Dialogue, 11(4), 414-426.

Sattler, S., Wiegel, C., \& van Veen, F. (2017). The use frequency of 10 different methods for preventing and detecting academic dishonesty and the factors influencing their use. Studies in Higher Education, 42(6), 1126-1144. https://doi.org/10.1080/03075079.2015.1085007

Seifried, E., Lenhard, W., \& Spinath, B. (2015). Plagiarism detection: A comparison of teaching assistants and a software tool in identifying cheating in a psychology course. Psychology Learning \& Teaching, 14(3), 236-249. https://doi.org/10.1177/1475725715617114

Singh, S., \& Remenyi, D. (2016). Plagiarism and ghostwriting: The rise in academic misconduct. South African Journal of Science, 112(5), 36-42.

Tasa, T. (2018). Tartu Ülikooli õppejõudude ja üliõpilaste arvamused plagiaadist ja plagiaadituvastussüsteemidest (magistritöö). Tartu: Tartu Ülikool.

Teixeira, A. A. C., \& Rocha, M. F. (2010). Cheating by economics and business undergraduate students: An exploratory international assessment. Higher Education, 59(6), 663-701. https://doi.org/10.1007/s10734-009-9274-1

Vaismoradi, M., Turunen, H., \& Bondas, T. (2013). Content analysis and thematic analysis: Implications for conducting a qualitative descriptive study. Nursing and Health Sciences, 15(3), 398-405. https://doi.org/10.1111/nhs.12048

Walker, J. (2010). Measuring plagiarism: Researching what students do, not what they say they do. Studies in Higher Education, 35(1), 41-59.

https://doi.org/10.1080/03075070902912994 


\title{
Students' views on plagiarism and plagiarism detection systems
}

\author{
Marvi Remmilk $^{\mathbf{a}^{1}}$, Tiina Tasa ${ }^{\mathrm{b}}$, Liana Roos ${ }^{\mathrm{c}}$, Erika Löfström ${ }^{\mathrm{d}}$ \\ a Viljandi Culture Academy, University of Tartu \\ ${ }^{b}$ Tartu Biotechnology Park \\ ${ }^{c}$ Institute of Education, University of Tartu \\ ${ }^{d}$ Department of Education, University of Helsinki
}

\section{Summary}

\section{Introduction}

Technological change along with the accessibility of different online sources has brought about a situation where plagiarism has turned into one of the most common forms of academic dishonesty (Chen \& Chou, 2017). The concept of plagiarism is complex and there isn't a good definition that covers all the different forms of plagiarism (Kayaoğlu et al., 2016). The most widely used definition describes plagiarism as using other author(s)'s work as one's own without a reference to the author(s) (Bokosmaty et al., 2017; Chen \& Chou, 2017; Gullifer \& Tyson, 2014; Moss et al., 2018). Furthermore, the meaning of plagiarism can be interpreted differently depending on the individual or the context where it occurs (Adam et al., 2017). Due to the lack of a comprehensive definition and the availability of unambiguous examples of plagiarisms there is still confusion among the students on what exactly plagiarism is. Confusion about plagiarism and how to avoid it among students along with the lack of academic writing skills have been referred to as reasons why plagiarism still occurs in student's work (Chankova, 2017; Chen \& Chou, 2017; Sarwar et al., 2016). Many authors distinguish plagiarism on the basis of whether it is intentional or not. For example, the reasons mentioned before point to unintentional plagiarism (Kayaoğlu et al., 2016). Intentional plagiarism appears when students are aware of the fact that they are conducting plagiarism. Lack of time, lack of time management skills, workload (Chankova, 2017; Kayaoğlu et al., 2016; Sarwar et al., 2016), laziness (Chen \& Chou, 2017), a negative attitude to homework (Chankova, 2017), lack of interest in the subject (Chen \& Chou, 2017), low probability of getting caught (Bokosmaty et al., 2017; Ewing et al., 2017; Kayaoğlu et al., 2016) and no fear of penalties (Chankova, 2017) are all

University of Tartu Viljandi Culture Academy, Posti 1, 71004 Viljandi, Estonia; marvi.remmik@ut.ee 
reasons for intentional plagiarism. Students' academic behaviour is also influenced by the faculties' attitudes to plagiarism (Marshall \& Garry, 2005). The confusion of faculty members about plagiarism and what it entails (Espinoza \& Nájera, 2015) and their inability to implement penalties (Pickard, 2006) send mixed signals to students. Studies have also shown that students recognise plagiarism as unethical but are not able to describe how to make a proper citation (Adam et al., 2017) or recognise different forms of plagiarism (Marshall \& Garry, 2005; Bokosmaty et al., 2017). Furthermore, students see some plagiarism as inevitable, as there is only a limited amount of ways how to present the same theme (Bokosmaty et al., 2017), so the prospect of perceived inevitability of making oneself guilty of some form of plagiarism scares them.

To solve the problem of plagiarism, cooperation between the faculty and the university is very important (Ewing et al., 2017). Unfortunately, common regulations on how to, on the one hand, prevent and, on the other hand, how to react to plagiarism is lacking in many universities and the faculty is left to deal with such situations on their own (Bokosmaty et al., 2017). Another way to decrease plagiarism is to use plagiarism detection systems which allow both the students as well as the faculty to check their texts (Walker, 2010). Most of the systems compare texts against those existing in various databases and websites (Seifried et al., 2015). Critics of the systems fear that plagiarism detection systems will only be used to check and punish rather than teach (Bruton \& Childers, 2016; Löfström \& Kupila, 2013). Löfström et al. (2017) found that using plagiarism detection systems make students more aware of their writing, and effective use of these systems involves familiarisation with the system and guidance from teachers and supervisors.

The focus of this article is to find out university students' views on plagiarism and plagiarism detection systems in a context where there has been increased national and institutional emphasis on anti-plagiarism strategies, and to offer suggestions on how universities and faculties can take charge of the situation that is considered by many with experience as unsustainable. The following four key research questions were formulated:

1. What are university students' views on plagiarism and the reasons for plagiarism?

2. What are university students' views on plagiarism detection systems?

3. What are the possible solutions to combat plagiarism according to university students themselves?

4. Do university students' views on plagiarism, plagiarism detection and ways to combat plagiarism differ depending on academic discipline? 


\section{Study design and selection of the subject}

The data was collected from bachelor's and master's students at Estonian universities. A survey-type questionnaire on student conceptions of plagiarism and plagiarism detection (Löfström \& Kupila, 2013) was adapted for the Estonian context and sent to students through faculty internal e-mail systems. The participation in the research was voluntary, and no identifying data were collected. Thus, the respondents remained anonymous. A total of 380 responses were received: 243 (64\%) from bachelor's students and 137 (36\%) from master's students. 102 (27\%) participants studied at the faculty of arts and humanities, $91(24 \%)$ at the faculty of science and technology, $50(13 \%)$ at the faculty of medicine and $137(36 \%)$ at the faculty of social sciences. $26 \%(n=99)$ of the participants were men and $74 \%(n=281)$ women.

The data analyses included a factor analysis with the Varimax rotation, the Mann-Whitney U-test, the Kruskal-Wallis one-way ANOVA test, and the analysis of internal consistency between factors using the Cronbach's alpha $(\alpha \geq 0.70)$ (Costello \& Osborne, 2005). The results were statistically significant when $p<0.05$. The responses to the open-ended questions were analysed through a thematic analysis in which we identified the categories of themes (the consequences of plagiarism, plagiarism detection systems as helpful tools, recommendations for improving the plagiarism detection systems) and divided the sub themes on the basis of contextual similarities under wider themes.

\section{Results}

The findings of the article corresponded to the previous findings (Chen \& Chou, 2017; Löfström \& Kupila, 2013; Pickard, 2006). Students see plagiarism as a problem but have difficulties identifying its extent. Furthermore, the reasons for plagiarism were consistent with Löfström et al. (2017), namely intentional plagiarism, unintentional plagiarism and plagiarism as a way of coping with studies. Both bachelor's (71\%) and master's students' (71.2\%) suggested that unintentional plagiarism is the most important reason for plagiarism. In different academic disciplines the results differed between the faculty of science and technology and other faculties. The students of science and technology assessed unintentional plagiarism reasons as less prevalent than students of other disciplines. Similarly, men assessed unintentional plagiarism as less prevalent than women. In addition, different forms of plagiarism were analysed, and it came out that the majority of students $(99.5 \%)$ rated using other student's work as their own as the most severe form of cheating. Many students, more so in medicine, and science and technology, were confused about different forms of plagiarism, and struggled to identify what constitutes plagiarism and what 
does not. Slightly over half of the students in the fields of science and technology did not identify problems with using other's work verbatim with citation but without quotation marks. Most students in medicine answered that they didn't know whether the scenarios provided in the survey constituted plagiarism or not. Furthermore, only $36.3 \%$ of the students assessed their knowledge about the consequences of plagiarism as "good" or "very good." Analysis of the open-ended questions showed that the students brought up exmatriculation as a consequence, but many also pointed out the reality of no consequences at all. As for the plagiarism detection systems: master's students used them more (28.5\%) than bachelor's students (14.4\%), however, very few have used them at all. Analysis of the open-ended questions showed that the students have many fears concerning plagiarism detection systems, such as false identification of plagiarism in the system and being wrongly punished. However. many students acknowledged the potential of plagiarism detection systems as an educational tool used by university teachers.

Results indicated that there is still a lot of confusion about plagiarism among university students and there are rather large differences in attitudes and knowledge to plagiarism and the use of plagiarism detection systems among students from different academic disciplines. The study highlights the importance of integrating the use of plagiarism detection systems with the pedagogical approaches to support students' learning.

Keywords: plagiarism, plagiarism detection systems, students, academic dishonesty 